\title{
Etnomatematika untuk Meningkatkan Kemampuan Pemecahan Masalah Matematis Siswa
}

\author{
Wahyu Cahyadi ${ }^{1}$, Miftah Faradisa, Sitri Cayani, Fatrima Santri Syafri \\ ${ }^{1}$ Institut Agama Islam Negeri Bengkulu \\ 1'wahyuchy4@gmail.com
}

\begin{tabular}{l}
\hline \hline Article Info \\
\hline Article history: \\
Received Dec $28^{\text {th }}, 2020$ \\
Revised Dec $31^{\text {th }}, 2020$ \\
Accepted Dec $31^{\text {th }}, 2020$ \\
\hline
\end{tabular}

Keywords:

Ethnomatematics;

Problem Solving

Kata Kunci:

Etnomatematika; Pemecahan Masalah
Abstract

This study aims to see the effects of ethnomatematics in improving students' mathematical problem skills. This research uses literature study method. In this research, the knowledge, ideas, or findings contained in it are studied, so as to provide theoretical and scientific information related to ethnomatematics in improving the ability of mathematical problems. The data analysis technique includes 3 stages are: 1) administration; 2) synthesis; and 3) identification. From existing studies, learning that applies ethnomathematics in it, both as a medium and as an approach, has a positive impact on the learning process, because learning is more directed and students feel happy while learning, because students can be directly involved in the learning process. The use of ethnomatematics also makes students closer to these lessons, because it uses local culture as a learning medium. Where students are very familiar with the culture in their place of residence. So that these things increase the ability to handle student problems.

\section{Abstrak}

Penelitian ini bertujuan untuk melihat pengaruh penggunaan etnomatematika dalam meningkatkan kemampuan pemecahan masalah matematis siswa. Penelitian ini menggunakan metode studi literatur. Dalam penelitian ini, dikaji pengetahuan, gagasan, atau temuan yang terdapat di dalamnya, sehingga memberikan informasi teoritis dan ilmiah terkait etnomatematika dalam meningkatkan kemampuan pemecahan masalah matematis. Teknik analisis data meliputi 3 tahap: 1) organize; 2) synthesize; dan 3) identify. Dari penelitian-penelitian yang menerapkan etnomatematika di dalamnya, baik itu sebagai media ataupun pendekatannya memberikan dampak yang 
positif terhadap proses pembelajaran, karena pembelajaran lebih terarah dan siswa merasa senang saat belajar, sebab siswa dapat terlibat secara langsung dalam proses pembelajaran. Penggunaan etnomatematika juga membuat siswa semakin dekat dengan pelajaran tersebut, karena menggunakan kebudayaan setempat sebagai media belajar. Di mana siswa sudah sangat akrab dengan kebudayaan yang ada di tempat tinggalnya. Sehingga hal-hal tersebut membuat kemampuan pemecahan masalah siswa menjadi meningkat.

\section{PENDAHULUAN}

Indonesia adalah sebuah negara yang memiliki ragam kebudayaan yang unik, dan sangat bervariasi. Ragam kebudayaan yang dimaksudkan adalah ras, suku, bahasa, kesenian, makanan, minuman, kebiasaan dan lain-lain. Dari ragam kebudayaan tersebut terciptanya ikon-ikon di setiap provinsi Indonesia bahkan menjadi ciri khas dari daerah tersebut, seperti wisata, kesenian daerah, makanan, dan lain-lain. Begitu juga dengan Provinsi Bengkulu yang memiliki berbagai kebudayaan yang unik, seperti alat musik (Dol), Festival Tabot, Rumah Adat (Bubungan Lima), makanan khas (Bay Tat), dan lain sebagainya.

Jika kita lihat setiap kebudayaan tersebut memiliki hubungan erat dengan matematika, seperti alat musik Dol sekilas berbentuk tabung, pada bangunan Tabot dan rumah adat Bubungan Lima memiliki beberapa bentuk di antaranya segitiga, persegi, persegi panjang, kubus, balok, jajargenjang dan lainnya, sedangkan pada kue Bay Tat memiliki bentuk segi empat. Suatu aktivitas yang melibatkan angka, pola geometri, hitungan dan sebagainya dianggap sebagai aplikasi pengetahuan matematika yang melibatkan budaya lokal, hal lebih dikenal sebagai ethnomathematics.

Matematika merupakan salah satu pelajaran yang memerlukan pemahaman. Namun, fakta menunjukkan bahwa di kalangan pelajar matematika menjadi pelajaran yang sulit untuk dipahami, membosankan dan terkesan tidak menarik. Sehingga, matematika menjadi pelajaran yang kurang disenangi oleh para siswa di setiap tingkatan sekolah. Hal ini merupakan salah satu faktor dari rendahnya kemampuan pemecahan 
siswa. Hal ini berdasarkan dari beberapa penelitian, diantaranya Kemendikbud melalui program Indonesia National Assesment Program (INAP) pada 2016 menunjukkan sekitar 77,13\% siswa SD di seluruh Indonesia memiliki kompetensi matematika yang sangat rendah, yakni 20,58\% cukup dan hanya 2,29\% yang kategori baik. Penelitian terbaru pada 2018, Program Research on Improvement of System Education (RISE) di Indonesia merilis hasil studinya yang menunjukkan bahwa kemampuan siswa memecahkan soal matematika sederhana tidak berbeda secara signifikan antara siswa baru masuk SD dan yang sudah tamat SMA.

Dalam pembelajaran matematika diperlukan kemampuan pemecahan masalah. Hal ini termasuk unsur penting dan berkaitan dengan matematika yang di dalamnya ada bermacam-macam masalah yang harus diselesaikan. Terdapat beberapa strategi yang dapat digunakan untuk meningkatkan kemampuan pemecahan masalah, diantaranya melalui empat langkah menyelesaikan masalah, yaitu: memahami masalah, merencanakan penyelesaian, menyelesaikan masalah sesuai rencana, dan mengecek hasil, Polya dalam Putri (2017).

Pandangan terhadap matematika adalah sulit, rumit dan jauh dari kehidupan sehari-hari menjadi penyebab tidak disenanginya pelajaran matematika. Kebanyakan materi siswa hanya diajarkan agar mempelajari matematika tanpa mengkoneksikannya dengan kehidupan nyata. Hal ini menyebabkan siswa ketika diberi soal yang berbeda dengan konsep yang sama akan mengalami kesulitan. Sebab matematika yang siswa dapatkan hanya sebatas cangkangnya belum pada makna dari konsep itu sendiri serta penggunaan dan penerapan dalam kehidupan sehari-harinya.

Pembelajaran matematika yang kurang dihubungkan dengan kehidupan nyata, akan menjadikan pembelajaran tersebut kurang bermakna. Pada kenyataannya pembelajaran matematika tidak dapat terlepas dari kehidupan sehari-hari. Kebermaknaan dalam pembelajaran sangat penting, karena akan memberikan bekas yang selalu diingat oleh siswa.

Istilah ethnomathematics atau etnomatematika diperkenalkan pertama kali pada tahun 1977 oleh seorang pendidik dan matematikawan 
dari Brazil yaitu Ubiratan D'ambrosio. Secara bahasa Etnomatematika terbagi menjadi tiga kata yaitu ethno, mathemat, tics. Kata pertama memiliki arti sesuatu yang sangat luas yang mengacu pada konteks sosial budaya, yang beberapa diantaranya bahasa, jargon, kode perilaku, mitos, dan simbol. Kata kedua berarti menjelaskan, mengetahui, memahami, dan melakukan kegiatan di mana meliputi pengkodean, mengukur, mengklasifikasi, menyimpulkan, dan pemodelan. Tics yang berasal dari techne, dan memiliki makna sama seperti teknik. Secara istilah etnomatematika dapat diartikan sebagai matematika yang diaplikasikan ke dalam suatu budaya, budaya tersebut meliputi kegiatan masyarakat nasional suku, kelompok buruh, anak-anak dari suatu kelompok tertentu.

Bishop dalam Hardiarti (2017) menyatakan bahwa suatu bentuk budaya tertentu dapat diartikan dengan matematika. Artinya, suatu budaya yang memiliki suatu konsep matematika dapat diartikan sebagai etnomatematika. Selanjutnya, Pinxten dalam Hardiarti (2017) menyatakan bahwa sebuah metode ilmiah tentang suatu lambang yang tumbuh pada aktivitas lingkungan yang bersifat budaya hal itu dapat diartikan dengan matematika yang telah dijabarkan dalam kehidupan. Dengan demikian seseorang memiliki kemampuan matematika tergantung dengan latar belakang yang mereka alami, karena seseorang akan melakukan sesuatu berdasarkan apa yang mereka rasakan dan mereka lihat. Perilaku individu dan perkembangan pemahaman individu dapat dipengaruhi oleh budaya karena itu dalam pembelajaran matematika sebuah budaya akan membantu peserta didik dalam meningkatkan kemampuannya. Hal ini sejalan dengan Wahyuni, dkk (2013) yang berpendapat bahwa etnomatematika dapat menjadi jembatan dalam pembelajaran matematika dengan budaya, artinya pembelajaran matematika dapat diajarkan melalui budaya di mana hal ini dapat disebut dengan etnomatematika.

Zulkifli dan Dardiri (2016) berpendapat bahwa praktik dari etnomatematika adalah suatu kelompok budaya yang mendemontrasikan suatu matematika. Dilanjutkan oleh Destrianti dkk (2019) yang mengemukakan bahwa etnomatematika dapat diartikan sebagai terapan matematika pada budaya yang terkait dengan kegiatan matematika seperti berhitung, mengukur, merancang bangunan atau alat, bermain, 
menentukan lokasi, dan lain sebagainya. Hal ini ditegaskan oleh Barton dalam Zulkifli (2016) yang mengatakan bahwa etnomatematika adalah di mana ketika suatu budaya tertentu dapat digunakan dalam memahami, mengekspresikan, dan menggunakan konsep-konsep serta praktik-praktik kebudayaannya yang digambarkan oleh peneliti sebagai sesuatu yang matematis.

D'Ambrosio dalam Rachmawati (2016) mengatakan bahwa suatu budaya matematika dapat berkembang dalam masyarakat pemakainya dan memiliki bentuk yang berbeda-beda sesuai dengan perkembangannya. Pendapat ini dilanjutkan oleh Bishop dalam Zulkifli (2016) yang menyatakan bahwa etnomatematika dapat dibagi menjadi enam kegiatan mendasar yang selalu dapat ditemukan pada sejumlah kelompok budaya. Keenam kegiatan di antaranya menghitung, menentukan lokasi, mengukur, mendesain, dan bermain sambil menjelaskan. Dari beberapa pendapat di atas dapat didefinisikan bahwa etnomatematika merupakan suatu cara yang melibatkan kebudayaan daerah sekitar dalam mempelajari matematika sehingga memudahkan seseorang memahami pembelajaran tersebut.

Menurut Permendiknas No. 23 Tahun 2006 dalam Imswatama (2018), komponen-komponen penting yang harus dimiliki peserta didik adalah kemampuan dalam memecahkan masalah. Hal ini sesuai dengan tujuan pembelajaran pada kurikulum satuan pendidikan yang menyatakan bahwa mata pelajaran matematika bertujuan agar peserta didik memiliki kemampuan sebagai berikut: (1) memahami konsep matematika, menjelaskan keterkaitan antar konsep yang kemudian mengaplikasikannya secara akurat, efisien, dan tepat dalam pemecahan masalah; (2) memecahkan masalah, seperti memahami masalah matematika, merancang masalah, dan menyelesaikan masalah matematika yang diperoleh; (3) mengkomunikasikan gagasan berupa simbol, tabel, diagram, atau media lain untuk memperjelas suatu masalah; (4) melakukan generalisasi, melakukan manipulasi matematika, menggunakan penalaran, menyusun bukti, atau menjelaskan gagasan dan pernyataan matematika; (5) memiliki sikap ulet, rasa ingin tahu, 
perhatian, percaya diri mempelajari matematika pada pemecahan masalah dalam kehidupan sehari-hari.

Untuk melihat tingkat kemampuan pemecahan masalah matematis siswa yang baik dilihat dari cara siswa dalam memahami permasalahan, merencanakan konsep matematika yang akan digunakan, mengubah ke dalam model matematika, menyelesaikan permasalahan ditutup dengan menyimpulkan sebuah masalah. Hal ini sejalan dengan pendapat Siswono dalam Muksin, dkk (2020) yang mengatakan bahwa pemecahan masalah adalah suatu proses atau upaya individu untuk merespons atau mengatasi halangan atau kendala ketika suatu jawaban atau metode jawaban belum tampak jelas. Arifin dan Aprisal (dalam Muksin, dkk 2020) menyatakan bahwa masalah matematika dapat diartikan sebagai suatu soal yang diberikan guru kepada siswa tapi tidak mempunyai aturan tertentu yang dapat digunakan untuk menemukan jawabannya. Menurut Rahman dan Ahmar dalam Muksin, dkk (2020) menambahkan bahwa kemampuan pemecahan masalah adalah salah satu kemampuan yang harus dimiliki siswa untuk menyadari pentingnya matematika dalam kehidupan seharihari.

Berdasarkan pendapat di atas dapat disimpulkan bahwa kemampuan pemecahan masalah adalah salah satu upaya yang harus dilakukan siswa dalam memahami suatu masalah untuk menenemukan jawaban yang belum diketahui aturan tertentu kemudian dapat menyelesaikan jawabannya. Adapun Indikator kemampuan pemecahan masalah menurut Polya dalam Putri (2017) sebagai berikut: 1) memahami masalah, siswa dapat mengumpulkan informasi-informasi yang diberikan dari pertanyaan yang diajukan; 2) merencanakan pemecahan, siswa dapat membuat rencana pemecahan masalah yang ia gunakan serta alasan penggunaannya; 3) melakukan rencana pemecahan, siswa dapat memecahkan masalah yang ia gunakan dengan hasil yang benar; 4) memeriksa kembali pemecahannya, siswa memeriksa kembali langkah pemecahan yang ia gunakan. 


\section{METODE PENELITIAN}

Metode penelitian yang digunakan adalah Penelitian Studi Literatur. Dalam penelitian jenis ini, dikaji pengetahuan, gagasan, atau temuan yang terdapat di dalamnya, sehingga memberikan informasi teoritis dan ilmiah terkait etnomatematika dalam meningkatkan kemampuan pemecahan masalah matematis. Data yang dianalisis merupakan data sekunder yang berupa hasil penelitian seperti buku bacaan ilmiah, jurnal ilmiah, laporan penelitian, situs internet dan lainya yang relevan. Teknik analisis data meliputi 3 tahap: Pertama. Organize di mana dalam tahap ini peneliti membaca 11 sumber bacaan yang berkaitan dengan etnomatematika dan kemampuan pemecahan masalah. Dari beberapa sumber didapatkan bahwa banyak pembelajaran menggunakan etnomatematika sebagai media belajar. Sehingga didapatkan bahwa adanya keterkaitan antara etnomatematika dalam kemampuan pemecahan masalah. Hal ini yang melandasi peneliti untuk membahas tentang etnomatematika dalam meningkatkan kemampuan pemecahan masalah. Tahap selanjutnya adalah Synthesize, ditahap ini peneliti mendapatkan ringkasan yaitu banyak dari model pembelajaran, media pembelajaran yang berbasis etnomatematika digunakan dalam proses belajar dan hal ini membantu siswa dalam meningkatkan kemampuan pemecahan masalah. Tahap selanjutnya adalah Identify, pada tahap ini peneliti mendapatkan beberapa isu bahwa tidak semua kebudayaan dapat digunakan dalam pembelajaran matematika, artinya setiap kebudayaan ada materi tersendiri yang dapat dipelajari.

\section{HASIL PENELITIAN DAN PEMBAHASAN}

Kemampuan pemecahan masalah atau sering disebut problem solving merupakan kemampuan menyelesaikan masalah rutin, non-rutin, rutin terapan, rutin non-terapan, non-rutin terapan dan masalah non-rutin non-terapan dalam bidang matematika (Lestari dan Yudhanegara, 2017). Artinya kemampuan yang dimiliki oleh peserta didik dalam menyelesaikan masalah, di mana dalam penyelesaian masalah tersebut diperlukan langkah-langkah untuk mendapatkan hasil penyelesaian. Dalam meningkatkan kemampuan diperlukan strategi khusus agar peserta didik dapat mengembangkan kemampuan itu salah satunya dengan 
etnomatematika. Etnomatematika yang akan menjadi sumber belajar bagi peserta didik agar mampu memudahkan guru dalam menyampaikan materi-materi yang terkait dengan matematika.

Media pembelajaran yang bernuansa etnomatematika menjadi salah satu cara untuk meningkatkan kemampuan pemecahan masalah. Hal ini dibuktikan oleh Cahyaningrum (2016) yang mengatakan dalam penelitiannya bahwa kemampuan pemecahan masalah siswa pada pembelajaran strategi REACT berbantuan modul etnomatematika lebih baik dari pada siswa dengan pembelajaran konvensional. Dilihat dari uji banding yang dilakukan. Uji banding yang dilakukan dalam penelitian itu yaitu uji beda rata-rata dua sampel independen. Berdasarkan hasil perhitungan diperoleh nilai $t$ sebesar 4,645 sedangkan $t$ table sebesar 1 , 67. Ini berarti $t_{\text {hitung }}>t_{\text {tabel }}$, maka kemampuan pemecahan masalah siswa kelas eksperimen yang diajar dengan strategi REACT berbantu modul etnomatematika lebih tinggi dibandingkan kelas konvensional. Hal ini bisa terjadi karena strategi REACT yang berbantu modul etnomatematika mempermudah siswa belajar dengan tahap-tahapnya yaitu relating (mengaitkan), experiencing (mengalami), applying (menerapkan), cooperating (bekerja sama), dan transferring (memindahkan). Sehingga pembelajarannya lebih terarah dan siswa merasa senang, karena terlibat langsung dalam proses pembelajaran tersebut. Terlebih lagi modulnya menggunakan etnomatematika yang membuat siswa semakin dekat dengan pelajaran tersebut, karena menggunakan kebudayaan setempat untuk belajar. Di mana siswa sudah sangat akrab dengan kebudayaan yang ada di tempat tinggalnya.

Sejalan dengan Utami dkk (2018) yang melakukan penelitian dengan judul penelitian "Pengembangan E-Modul Berbasis Etnomatematika untuk Meningkatkan Kemampuan Pemecahan Masalah" yang menyimpulkan bahwa proses pengembangan e-modul pembelajaran matematika kelas VII SMP berbasis etnomatematika yang telah teruji valid. Sedangkan hasil uji keterbacaan menunjukkan bahwa bahasa yang digunakan dalam e-model matematika berbasis etnomatematika adalah bahasa yang mudah dipahami dan tidak mengandung makna ganda. Berdasarkan perolehan rata-rata nilai validator media, validator materi 
dan validator budaya yang tinggi dapat disimpulkan jika pengembangan e-modul berbasis etnomatematika dapat meningkatkan kemampuan pemecahan masalah, terlebih e-modul yang dikembangkan menghadirkan konten-konten kebudayaan dalam materi. Sehingga siswa lebih cepat memahami pembelajaran tersebut.

Imswatama dan Lukman (2018) menambahkan bahwa bahan ajar matematika berbasis etnomatematika terbukti efektif dalam pemecahan keterampilan masalah. Artinya, ketika peserta didik belajar menggunakan bahan ajar atau modul yang bernuansa etnomatematika mendapatkan hasil yang baik. Hal ini dikarenakan dalam proses pembelajaran yang dilakukan oleh peserta didik akan efektif dengan bantuan bahan ajar atau modul yang bernuansa etnomatematika. Dari segi proses pembelajaran, etnomatematika dapat dikolaborasikan dengan strategi pembelajaran sehingga menciptakan hasil belajar yang baik. Hal ini menjawab pertanyaan Amor, dkk (2016) yang diperoleh menggunakan angket di mana peserta didik merasa tidak tertarik belajar matematika jika materi yang sampaikan tanpa ada kaitannya dengan kehidupan sehari-hari (etnomatematika).

Dari pendapat-pendapat di atas maka dapat dilihat bahwa penggunaan bahan ajar yang menerapkan etnomatematika di dalamnya dapat membantu siswa dalam mengasah kemampuan pemecahan masalah hal ini bisa dilihat dari beberapa faktor, di antaranya: pembelajaran lebih terarah, penggunaan konten-konten kebudayaan dalam pembelajaran, dan etnomatematika yang dapat dikolaborasikan dengan metode maupun strategi pembelajaran sehingga pembelajaran dapat lebih efektif.

Sehinggga dapat disimpulkan bahwa kemampuan pemecahan masalah peserta didik dapat ditingkatkan dengan melakukan pembelajaran yang menerapkan atau menggunakan etnomatematika di dalamnya, seperti penggunaan bahan ajar atau media pembelajaran. Berbagai jenis budaya yang beragam akan membuat peserta didik lebih tertarik bahkan mampu meningkatkan kemampuan pemecahan masalah dari dalam dirinya. Karena kebudayaan tersebut telah lekat dengan kehidupan seharihari siswa. 


\section{SIMPULAN}

Berdasarkan uraian di atas, dapat disimpulkan bahwa etnomatematika dapat meningkatkan kemampuan pemecahan masalah matematis siswa dalam pembelajaran matematika. Etnomatematika akan membantu siswa dalam mempelajari, menganalisis dan mempraktekkan kegiatan pembelajaran khususnya pada materi bangun datar dengan penggunaan pengerjaan pemecahan masalah yang relevan dengan budaya sebagai bahan ajar dan alternatif dalam pembelajaran.

\section{DAFTAR PUSTAKA}

Amor, D., Phys, J., Ser, C., Kusuma, D. A., Dewanto, S. P., \& Nurani, B. (2016). The role of ethnomathematics in West Java (a preliminary analysis of case study in Cipatujah). Journal of Physics: Conference Series PAPER. 3(2). https://iopscience.iop.org/article /10.1088/1742-6596/893/1/012020.

Beatty, Amanda Beatty, Emilie Berkhout, dan Daniel Suryadarma. (2019). Mengapa kemampuan matematika siswa Indonesia makin menurun. Program RISE di Indonesia. http://rise.smeru.or.id/id/ blog/mengapa-kemampuan-matematika-siswa-indonesia-makinmenurun.

Cahyaningrum, Nugraheni. (2016). Pembelajaran React berbantuan Modul Etnomatematika Mengembangkan Karakter Cinta Budaya Lokal dan Meningkatkan Kemampuan Pemecahan Masalah. Jurnal UNNES. UJMER. 5(1). https://journal.unnes.ac.id/sju/ index.php/ujmer/article/view/12917/7050.

Destrianti, Sindi. (2019). Etnomatematika dalam Seni Tari Kejei Sebagai Kebudayaan Rejang Lebong. Jurnal Equation. 2(2). https://ejournal.iainbengkulu.ac.id/index.php/equation/article/view 12316.

Hardiarti, Sylviyani. (2017). Etnomatematika: Aplikasi Bangun Datar Segiempat Pada Candi Muaro Jambi. Jurnal Aksioma. 8(2). https://www.google.com/url?sa=t\&source=web\&rct=j\&url=http:// journal.upgris.ac.id/index.php/aksioma/article/view/1707\&ved=2a 
hUKEwiyzr_YueXsAhVPX30KHeyGDQAQFjADegQICRAB\&u sg=AOvVaw2Zncu-NjO8Agj_8jIctbVR.

Imswatama, Aritsya dan Hamidah Suryani Lukman. (2018). Penerapan Bahan Ajar Matematika Berbasis Etnomatematika Terhadap Kemampuan Pemecahan Masalah Matematis Siswa. Jurnal Seminar Nasional Pendidikan Matematika. 01. 95. https://www.google.com/url?sa=t\&source=web\&rct=j\&url=https:/ /journal.uhamka.ac.id/index.php/senamku/article/download/2656/ 778/\&ved=2ahUKEwiPtLH0wuXsAhUMfX0KHeDHDJIQFjAAe gQIAxAC\&usg=AOvVaw2Zay3-K2tTW89_905lotiJ\&cshid=160 4377391835.

Lestari, Kurnia Eka. dan Yudhanegara, Mokhammad Ridwan. (2017). Penelitian Pendidikn Matematika. Bandung. PT. Refika Aditama.

Muksin, dkk. (2020). Pengaruh Model Pembelajaran Pair Checks Berbasis Tugas Pengajuan Masalah Terhadap Kemampuan Pemecahan Masalah Matematis Siswa. Jurnal Didaktik Matematika. 7(2). 187-188. http://jurnal.unsyiah.ac.id/DM/article/ download/17334/12951.

Putri, Ike Evitasari. (2017). Kemampuan Pemecahan Masalah Sistem Linear Dua Variabel Ditinjau Dari Kecerdasan Logis Matematis dan Gender. Prosiding SI MaNIs (Seminar Nasional Integrasi Matematika dan Nilai Islam). 1(1). 618. http://conferences.uinmalang.ac.id/index.php/SIMANIS/article/download/146/180.

Rahmawati Sri, Fitriatien. (2016). Pembelajaran Berbasis Etnomatematika. Jurnal Conference Paper. https://scholar.goo gle.co.id/citations?user=3f5Ihj4AAAAJ\&hl=id\#d=gs_md_cita-d\& $\mathrm{u}=\% 2 \mathrm{Fcitations} \% 3 \mathrm{Fview}$ _op\%3Dview_citation\%26hl\%3Did\% 26 user\%3D3f5Ihj4AAAAJ\%26citation_for_view\%3 D3f5Ihj4AAA AJ\%3AufrVoPGSRksC\%26tzom\%3D-420.

Rino, Richardo. (2016). Peran Etnomatematika dalam Penerapan Pembelajaran Matematika Pada Kurikulum 2013. Jurnal Literasi. 7(2). https://ejournal.almaata.ac.id/index. php/LITERASI/artcle/vi ew/383. 
Sugiyono. (2018). Metode Penelitian Kuantitatif, Kualitatif, dan $R \& D$. Bandung. CV Alfabeta.

Syaputra, Dedy. (2016). Etnomatematika pada Kegiatan Mengambil Madu oleh Suku Anak Dalam pada Kaitannya dengan Teori Belajar Konstruktivisme. Jurnal Repository Universitas Jambi. http://repository.fkip.unja.ac.id/file?i=dh60bWkA9d3eYhihu3UXi MedDig4uR361x6gAUh8ErA.

Karinawati. Asri. (2016). Pengaruh Pembelajaran Etnomatematika Sunda terhadap Kemampuan Pemecahan Masalah Matematis Siswa Sekolah Dasar. Jurnal Repository UPI. http://repository. upi.edu/id/eprint/22624.

Kementerian Pendidikan dan Kebudayaan (Balitbang - Pusat Penilaian Pendidikan). (2016). Hasil Indonesian National Assesment Programme (INAP). https://pusmenjar.kemdikbud.go.id/inap-sd/.

Utami dkk. (2018). Pengembangan E-Modul Berbasis Etnomatematika Untuk Meningkatkan Kemampuan Pemecahan Masalah. JNPM (Jurnal Nasional Pendidikan Matematika). 2.2. 268. http://jurnal. unswagati.ac.id/index.php/JNPM/article/view/1458.

Wahyuni, Astri, Ayu Aji W T, \& Budiman Sani. (2013). Peran Etnomatematika dalam Membangun Karakter Bangsa. Makalah Dipresentasikan dalam Seminar Nasional Matematika dan Pendidikan Matematika dengan Tema "Penguatan Peran Matematika dan Pendidikan Matematika Untuk Indonesia yang Lebih Baik". Jurusan Pendidikan Matematika FMIPA UNY. https://eprints.uny.ac.id/10738/.

Zulkifli, M. dan Dardiri. (2016). Etnomatematika dalam Sistem Pembilangan pada Masyarakat Melayu Riau. Jurnal Penelitian Sosial Keagamaan. 19.227. https://www.google.com/url?sa=t\& source=web\&rct=j\&url=http://ejournal.uin-suska.ac.id/index.php/ Kutubkhanah/article/download/2552/1616\&ved=2ahUKEwjS2Oj6 uOXsAhWBf30KHajRADoQFjAAegQIBBAC\&usg=AOvVaw17 d6XW4IPKohR0dEFZDwik. 